\title{
Platinum Uptake from Chloride Solutions Using Biosorbents
}

\author{
Mehmet Hakan Morcali*, Bihter Zeytuncu, Onuralp Yucel \\ Istanbul Technical University, Faculty of Chemical and Metallurgical Engineering, \\ Maslak, 34469, Istanbul, Turkey
}

Received: June 29, 2012; Revised: November 22, 2012

\begin{abstract}
Present work investigates platinum uptake from synthetically prepared, dilute platinum-bearing solutions using biomass residues, i.e. pistachio nut shell and rice husk, which are abundant in Turkey, and provides a comparison between these two biosorbents. Effects of the different uptake parameters, sorbent dosage, contact time, temperature and $\mathrm{pH}$ of solution on platinum uptake (\%) were studied in detail on a batch sorption. Before the pistachio nut shell was activated, platinum uptake (\%) was poor compared to the rice husk. However, after the pistachio nut shell was activated at $1000{ }^{\circ} \mathrm{C}$ under an argon atmosphere, the platinum uptake (\%) increased two-fold. The pistachio nut shell (original and activated) and rice husk were shown to be better than commercially available activated carbon in terms of adsorption capacity. These two sorbents have also been characterized by FTIR and SEM. Adsorption equilibrium data best complied with the Langmuir isotherm model. Maximum adsorption capacities, $\mathrm{Q}_{\max }$, at $25^{\circ} \mathrm{C}$ were found to be 38.31 and $42.02 \mathrm{mg} . \mathrm{g}^{-1}$ for the activated pistachio nut shell and rice husk, respectively. Thermodynamic calculations using the measured $\Delta \mathrm{H}^{\circ}, \Delta \mathrm{S}^{\circ}$ and $\Delta \mathrm{G}^{\circ}$ values indicate that the uptake process was spontaneous and endothermic. The experimental data were shown to be fit the pseudo-second-order kinetic model.
\end{abstract}

Keywords: adsorption, biomass, isotherms, platinum

\section{Introduction}

Recently, platinum uptake from aqueous solutions via resins or waste materials has received considerable attention because platinum is appreciably present in electronic parts, catalytic converters and plating materials due to its high resistance to oxidation ${ }^{1}$.

Uptake, i.e. adsorption, is widely applied in environmental treatment applications around the world. Liquid-solid adsorption systems are based on the ability of certain solids to preferentially concentrate specific substances from solutions onto their surfaces. This ability can be used for the removal of pollutants, such as metal ions and organic compounds, from wastewater ${ }^{2-5}$.

Over the past decade, significant research efforts have been directed to finding low cost, high capacity adsorbents for the removal of metal ions. A wide range of adsorbents have been developed and tested, including several activated carbons $^{6-9}$. In addition, a number of low cost agricultural wastes, such as rice husk, pistachio nut shell, tree fern, peat coal and chitosan, have been used for the removal of a range of metal ions. In particular, several natural resources have been studied for platinum recovery, including activated carbon ${ }^{1}$, chitosan ${ }^{10}$ and ion-exchange resins ${ }^{11}$.

Adsorption methods are widely used and are very effective in low metal concentrations. Among the different sorbent types, synthetic ion-exchange resins offer substantial advantages, such as high selectivity, good kinetic properties, and the following convenient forms for use: granules, powders, fibers, and filters. Majority of these resins are based on organic matrices with chemically bound functional groups that coordinate to or chelate metal ions.

*e-mail: hakanmorcali@gmail.com
In Turkey, agricultural by-products and waste materials that are available in large quantities may have the potential to be used as low-cost adsorbents. Conversion of agricultural waste materials into activated carbon adds considerable economic value, helps to reduce the cost of waste disposal, and most importantly provides a potentially inexpensive alternative to the existing commercial activated carbons.

There are many studies in the literature on preparation of activated carbons from agricultural wastes, such as sunflower seed hull, peanut hull, wheat bran, coir pith, banana pith, date pits, cotton stalks, palm tree, barley husk, palm kernel shell, rice husk, pinewood and soy hull ${ }^{12-18}$.

In this work, pistachio nut shell and rice husk, an agricultural by-product, were used to uptake platinum from dilute platinum chloride solutions. The objective of this study was to describe an effective uptake process using either pistachio nut shell or rice husk and to compare the two biosorbents by describing the optimal conditions and parameters for uptake platinum, including the adsorption isotherms of platinum ions and the kinetics and thermodynamics of the adsorption process. For these reasons, the following parameters were studied to investigate their effect on the uptake percentage of platinum: sorbent dosage, contact time temperature and $\mathrm{pH}$ of solution.

\section{Material and Methods}

\subsection{Experimental procedures}

The rice husk $(\sim 250 \mu \mathrm{m}$ thick) was obtained from the Gokbayrak Company, Turkey. The pistachio nut shell was obtained from the Gazi Fistikcilik Company, Turkey. The 
activated pistachio nut shell ( $250 \mu \mathrm{m}$ thick) was used for all experiments.

Platinum-containing solutions for the experiments were prepared with hexachloroplatinic acid $\left(\mathrm{H}_{2} \mathrm{PtCl}_{6}\right)$ standard solution (Merck, Germany). Distilled water (Smart 2 Pure) was used for wet chemical analyses.

This study was conducted using a batch system by changing one parameter at a time. For each experiment, $5 \mathrm{cc}$ of a platinum solution was brought into contact with the sorbent (rice husk, pistachio nut shell, or the activated pistachio nut shell) in a falcon tube to avoid exposure to air. Falcon tubes were shaken in a temperature-controlled water bath at a manually adjusted shaking rate of $100 \mathrm{rpm}$. The initial platinum ion concentrations were $100 \mathrm{mg} . \mathrm{L}^{-1}$, $150 \mathrm{mg} . \mathrm{L}^{-1}, 200 \mathrm{mg} . \mathrm{L}^{-1}$ and $250 \mathrm{mg} . \mathrm{L}^{-1}$.

First experimental series examined the effect of changing the sorbent dosage. Second experimental series were investigated the effect of altering the contact time from 15 to 120 minutes. The third experimental series explored the influence of temperature, which ranged from $25^{\circ} \mathrm{C}$ to $45^{\circ} \mathrm{C}$. In the fourth experimental series, the effect of solution $\mathrm{pH}$ was evaluated. For this purpose, hydrochloric acid and sodium hydroxide were employed to adjust the $\mathrm{pH}$ level of the solution. Final experimental series, investigated the adsorption kinetics, isotherm and thermodynamics.

Solid/liquid separation was performed using a Whatman No. 1 filter paper, following each run. After filtration, the filtrate was washed with distilled water to ensure that all of the platinum containing solution passed through the filter paper. For the ICP analysis, each filtered solution was introduced into the instrument following an appropriate dilution.

Percentage of platinum uptake was calculated using the following equation ${ }^{19}$ :

Platinum Uptake, $\%=\left[\left(C_{\mathrm{o}}-C_{\mathrm{t}}\right) / C_{\mathrm{o}}\right] * 100$

Adsorption capacity of the platinum ion was calculated using the following general equation ${ }^{19}$ :

$q_{\mathrm{e}}=\left[\left(C_{\mathrm{o}}-C_{\mathrm{t}}\right) * V\right] / m$

in which $\mathrm{q}_{e}$ is the amount of metal ions adsorbed at equilibrium per unit weight of sorbent $\left(\mathrm{mg} \cdot \mathrm{g}^{-1}\right), \mathrm{C}_{\mathrm{o}}$ and $\mathrm{C}_{\mathrm{t}}$ (mg. $\mathrm{L}^{-1}$ ) are the platinum ion concentrations present in the solution before and after adsorption, respectively, $\mathrm{V}$ is the volume of the solution (in L), and $\mathrm{m}$ is the amount of sorbent (in $\mathrm{g}$ ) used in the adsorption experiment.

\subsection{Preparation and characterization of sorbents}

The dry rice husk and pistachio nut shell were crushed using a crushing mill. The resulting recovered product was washed several times with distilled water to eliminate water soluble impurities and then dried in an oven at $105^{\circ} \mathrm{C} .500 \mathrm{~g}$ of the small pieces from pistachio nut shell was placed in a horizontal furnace in an inert atmosphere at $1000{ }^{\circ} \mathrm{C}$ for 3 hours. It was then removed from the furnace and cooled in a desiccator. After cooling, the rice husk and the activated pistachio nut shell were subsequently subjected to a homogenization treatment using a three-dimensional shaker for 1 hour.
The surface area of activated pistachio nut shell was measured by nitrogen adsorption at $77 \mathrm{~K}$ with a porosimeter. The sample was degassed at $623 \mathrm{~K}$ at $10^{-5}$ mbar overnight prior to the adsorption experiment. Surface area of the material was then measured. Surface area of activated pistachio nut shell was found $141.18 \mathrm{~m}^{2} \cdot \mathrm{g}^{-1}$. FTIR was used to identify some characteristic functional groups. Figures 1 and $2 \mathrm{a}, \mathrm{b}$ displays the IR spectra analysis carried out on rice husk and pistachio nut shell and activated pistachio nut shell, respectively.

Figure 1 displays the FTIR analysis carried out on rice husk. As can be seen in the figure, IR spectra of rice husk in the region $1200-1000 \mathrm{~cm}^{-1}$ were considered to result from superposition of vibrations of the $\mathrm{C}-\mathrm{OH}$ bond and $\mathrm{Si}-\mathrm{O}$ bond in the siloxane $(\mathrm{Si}-\mathrm{O}-\mathrm{Si})$ groups. Intense band at $1053 \mathrm{~cm}^{-1}$ corresponds to the stretching vibrations of silicon-oxygen tetrahedrons as $\left(\mathrm{SiO}_{4}\right)$. High intensity of this peak was probably due to superposition of the stretching vibrations of the C-OH bond in the interval $1200-1000 \mathrm{~cm}^{-1}$ and the stretching vibrations of the $\mathrm{Si}-\mathrm{O}$ bond. The absorbance peak at $442 \mathrm{~cm}^{-1}$ was due to the bending vibration of siloxane bonds ${ }^{20}$.

As can be seen in Figure 2a, hydroxyl groups $(\mathrm{O}-\mathrm{H})$ are usually in the range of $3200-3650 \mathrm{~cm}^{-1}$ for alcohols and phenols, aliphatic groups $(\mathrm{C}-\mathrm{H})$ located at around 2876$1370 \mathrm{~cm}^{-1}$. The band appearing at $1730 \mathrm{~cm}^{-1}$ was attributed to the carbonyl $(\mathrm{C}=\mathrm{O})$ groups. Carboxylate groups (band at $1332 \mathrm{~cm}^{-1}$ ), esters- ethers -phenol groups (bands at 1237 , $1155 \mathrm{~cm}^{-1}$ ), alcohol groups (band at $1027 \mathrm{~cm}^{-1}$ ) and the band at $897 \mathrm{~cm}^{-1}$ assigned to benzene derivative vibrations are located ${ }^{21}$. It is evident from Figure $2 b$ that IR spectra of activated pistachio nut shell in the region $2100-1900 \mathrm{~cm}^{-1}$ was considered to result from superposition of vibrations of the alkyne groups $(\mathrm{C} \equiv \mathrm{C})$ bond. Finally all oxygen groups, such as ether and alcohol, as well as other groups were destroyed during the activation, resulting in activation of the carbon incorporated in the structure ${ }^{1}$.

\section{Results and Discussion}

The following results outline the factors that play a role in platinum uptake and the conditions for attaining maximum platinum uptake $(\%)$.

\subsection{Effect of sorbent dosage on platinum adsorption (\%)}

Dosages of the rice husk, pistachio nut shell and activated pistachio nut shell were varied in the range of 2 to $20 \mathrm{mg} \cdot \mathrm{cm}^{-3}$ of $100 \mathrm{ppm}$ platinum solution in the first experimental series. Figure 3 presents the platinum uptake (\%) with increasing sorbent dosages.

The platinum uptake (\%) is found to increase with increasing sorbent dosage because the uptake reactions are thermodynamically more favorable when the sorbent-tometal ion ratio is high ${ }^{20}$. This is an expected result because as the amount of sorbent increased; an increasing amount of surface area became available, which exposed more active sites for binding metal ions. A similar trend for the effect of sorbent concentration was observed in a study by Aktas and Morcali ${ }^{1}$. 
The pistachio nut shell was not able to adsorb the platinum ions with high percentages, even if it was used in excessive quantities (e.g., $20 \mathrm{mg} . \mathrm{cm}^{-3}$ ). However, after the pistachio nut shell was activated under an argon atmosphere at $1000{ }^{\circ} \mathrm{C}$, it was equally successful as the rice husk at adsorbing the platinum ions. For a 60 minutes

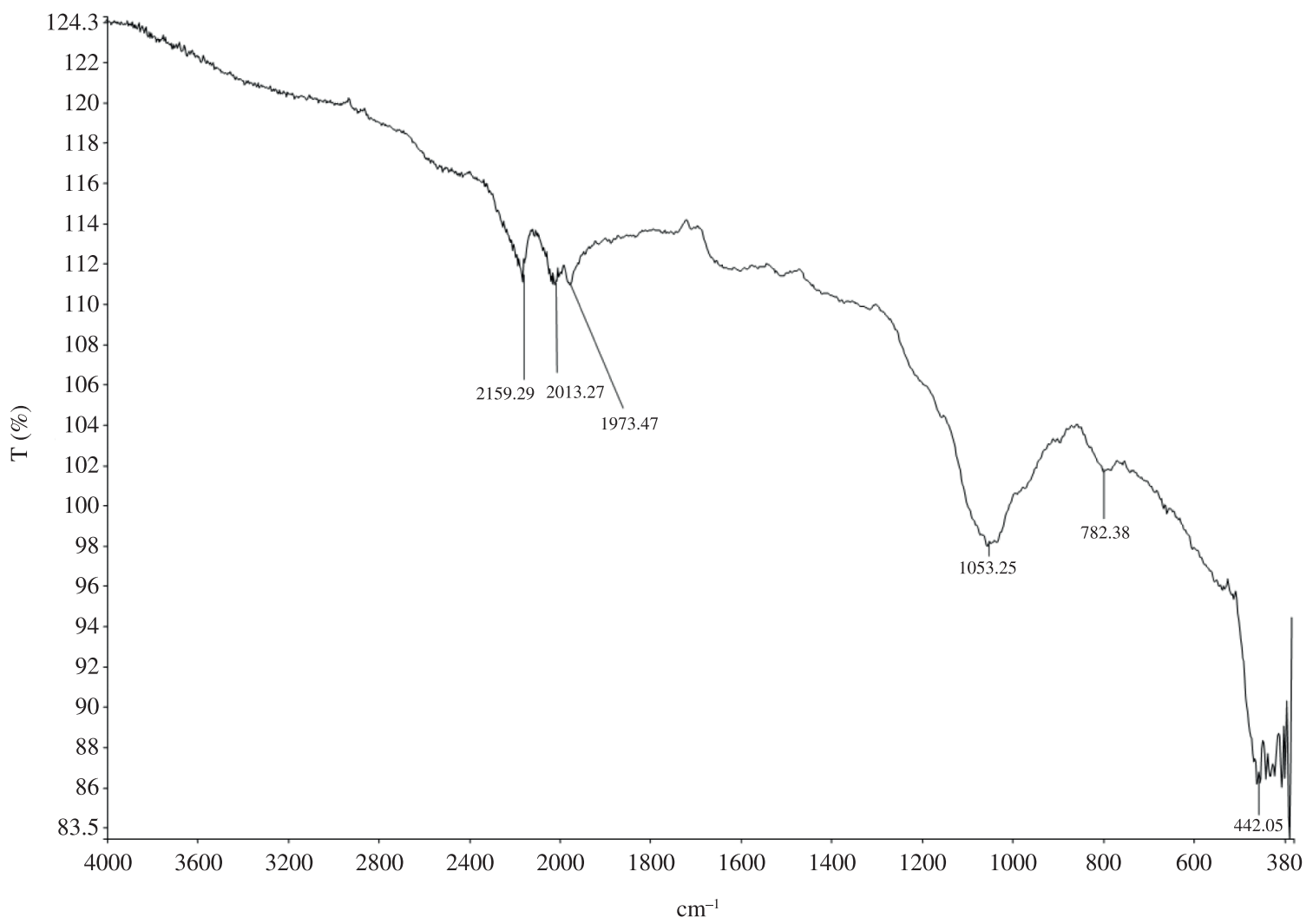

Figure 1. FTIR spectra of Rice husk.

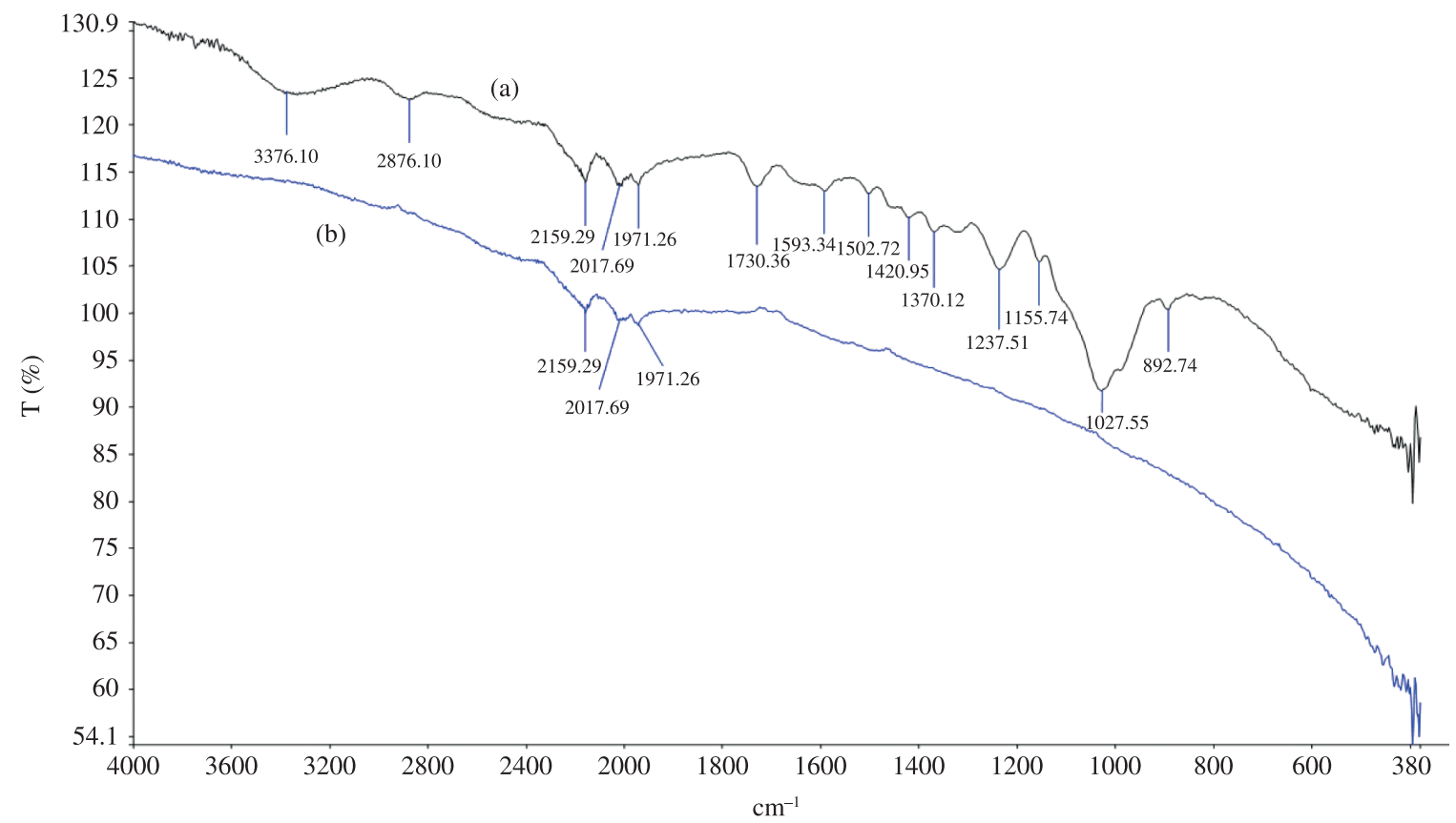

Figure 2. FTIR spectra of a) Pistachio nut shell and b) Activated pistachio nut shell. 
contact time with the platinum-containing solution, the rice husk $\left(4 \mathrm{mg} . \mathrm{cm}^{-3}\right)$ exhibited a platinum uptake $(\%)$ of $80 \%$; with $8 \mathrm{mg} \cdot \mathrm{cm}^{-3}$ of the rice husk, $95 \%$ of the platinum was adsorbed. Similarly, for a 60 minutes contact time, $95 \%$ of the platinum was adsorbed using $8 \mathrm{mg} \cdot \mathrm{cm}^{-3}$ of the activated pistachio nut shell.

\subsection{Effect of time on the platinum adsorption (\%)}

In this experimental series, the effect of contact time on platinum uptake (\%) was studied in the range of 15 to 120 minutes. Figure 4 presents the platinum uptake (\%) as a function of the contact time.

Figure 4 demonstrates that increasing the contact time has a positive effect on the platinum uptake (\%) (i.e., the platinum uptake (\%) increases with increasing time).

Figure $4 \mathrm{a}, \mathrm{b}$ show that the adsorption of platinum reached equilibrium after 15 minutes, i.e., there is no significant increase in uptake percentage after 15 minutes. Initially, this rate was higher because of all the adsorption sites on the rice husk and activated pistachio nut shell were vacant and the concentration was high, but after 15 minutes, all adsorption sites were filled with platinum ions, resulting in unchanged uptake percentages.

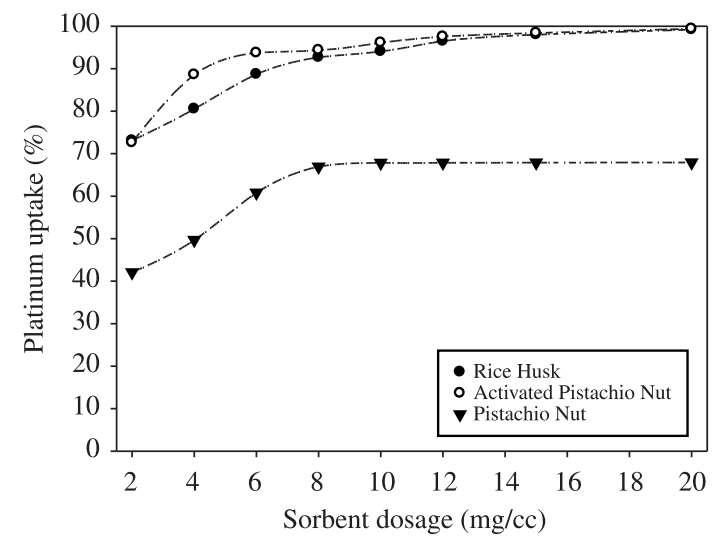

Figure 3. The effect of increasing sorbent dosage on platinum uptake (\%) $\left(60\right.$ minutes, $25^{\circ} \mathrm{C}, 100 \mathrm{rpm}, \mathrm{pH}=1.5$, and $5 \mathrm{cc} \mathrm{sol}$.).

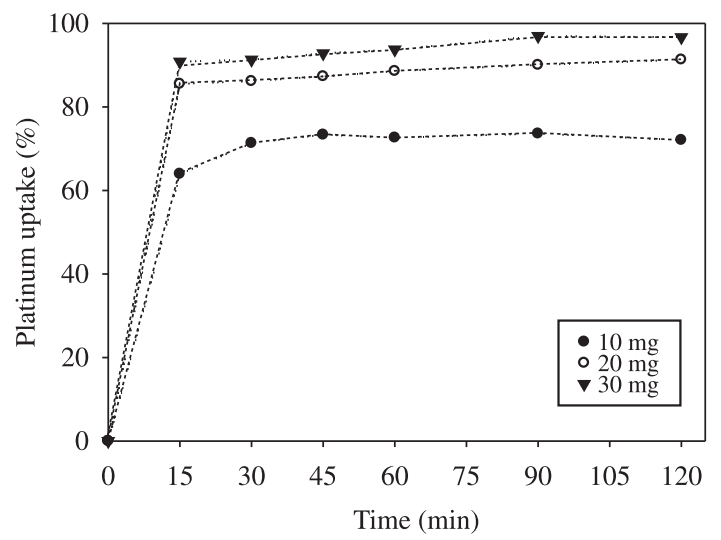

(a)
To analyze the adsorption rates of platinum ions onto the activated pistachio nut shell and rice husk, two different kinetic models were applied.

\subsection{Adsorption kinetics}

To investigate the controlling mechanism of the adsorption process, e.g., mass transfer or chemical reaction, the pseudo-first-order and pseudo-second-order rate equations were studied for the uptake of platinum ions by the activated pistachio nut shell and rice husk.

\subsubsection{Pseudo-first-order rate equation}

The pseudo-first-order rate expression, popularly known as the Lagergren equation, is generally described by the following equation ${ }^{22}$ :

$d q / d t=k_{a d}\left(q_{e}-q_{t}\right)$

where $\mathrm{q}_{\mathrm{e}}$ is the amount of metal ions adsorbed at equilibrium per unit weight of sorbent $\left(\mathrm{mg} \cdot \mathrm{g}^{-1}\right), \mathrm{q}_{\mathrm{t}}$ is the amount of metal ions adsorbed at any time $\left(\mathrm{mg} \cdot \mathrm{g}^{-1}\right)$, and $\mathrm{k}_{\mathrm{ad}}$ is the rate constant $\left(\mathrm{min}^{-1}\right)$. Integrating and applying the boundary conditions from $\mathrm{t}=0$ and $\mathrm{q}=0$ to $\mathrm{t}=\mathrm{t}$ and $\mathrm{q}=\mathrm{q}_{\mathrm{t}}$, Equation 3 takes the form:

$\ln \left(q_{e}-q_{t}\right)=\ln q_{e}-k_{a d} * t$

To determine the rate constants, straight-line plots of $\ln \left(q_{e}-q_{t}\right)$ versus $t$ (time) are shown in Figure 5. These plots exhibit straight lines for the activated pistachio nut shell material and the rice husk. The intercept of this plot results in $\ln \mathrm{q}_{\mathrm{e}}$.

\subsubsection{Pseudo-second-order rate equation}

The adsorption data were also analyzed in terms of a pseudo-second-order mechanism given by ${ }^{23}$ :

$d q / d t=k_{2}\left(q e-q_{t}\right)^{2}$

where $\mathrm{k}_{2}$ is the rate constant (g/min.mg). Integrating the above equation and applying the boundary conditions, i.e., $\mathrm{t}=0$ for $\mathrm{q}=0$ and $\mathrm{t}=\mathrm{t}$ for $\mathrm{q}=\mathrm{qt}$, gives:

$t / q_{t}=1 /\left(k_{2} * q_{e}^{2}\right)+1 / q_{e} * t$

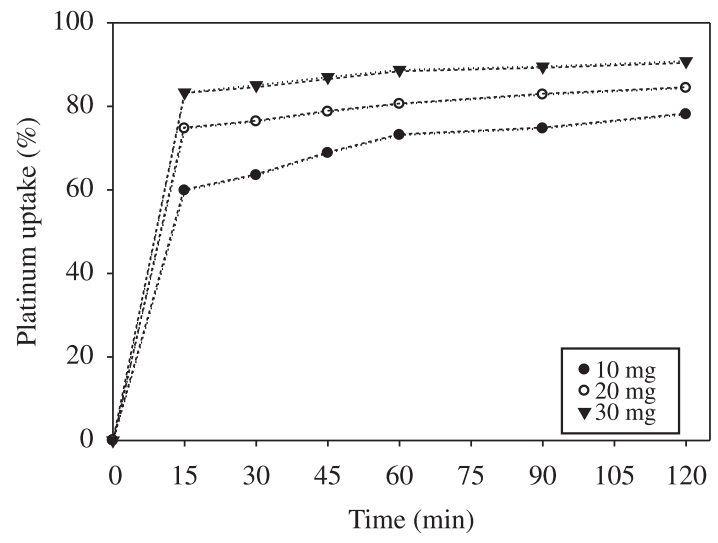

(b)

Figure 4. Platinum uptake $(\%)$ as a function of contact time by the a) activated pistachio nut shells and by b) Rice $\mathrm{Husk}\left(25^{\circ} \mathrm{C}, 100 \mathrm{rpm}\right.$, $\mathrm{pH}=1.5$, and $5 \mathrm{cc}$ sol.). 


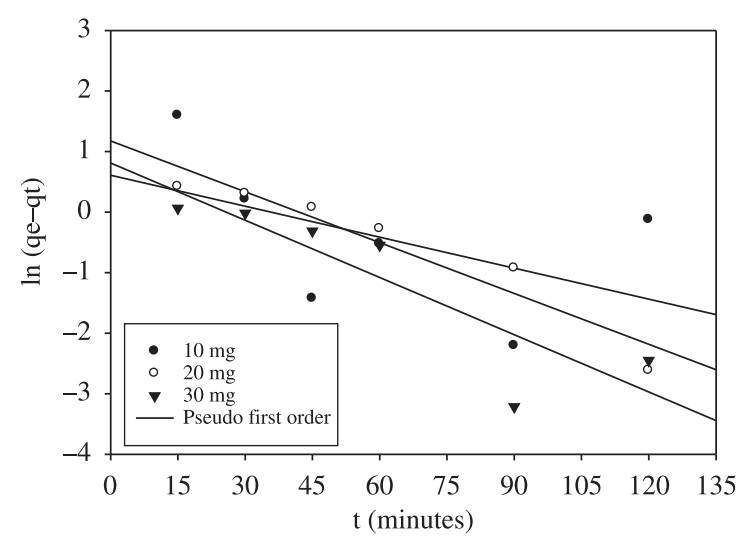

(a1)

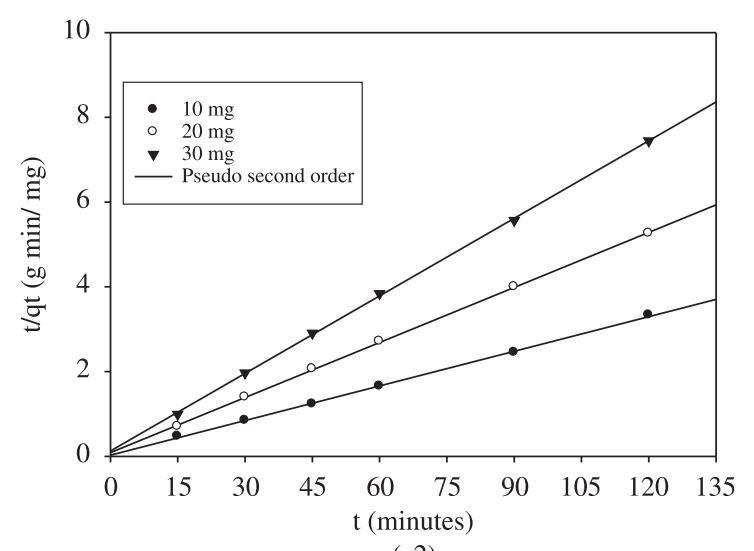

(a2)

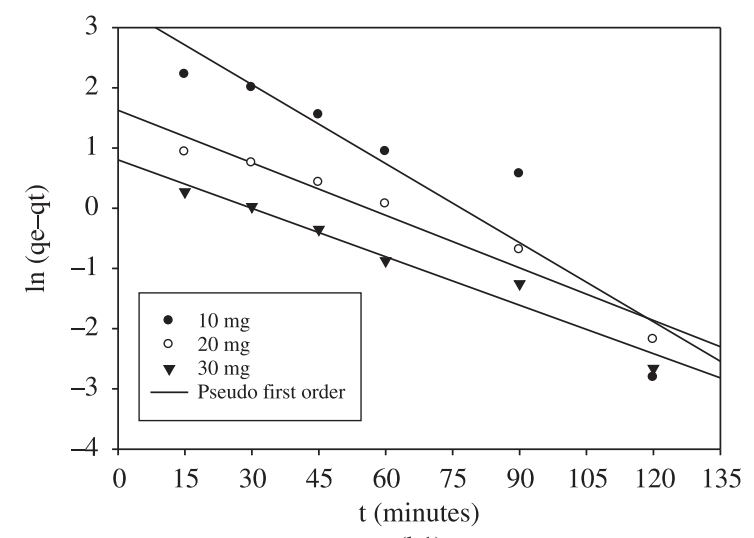

(b1)

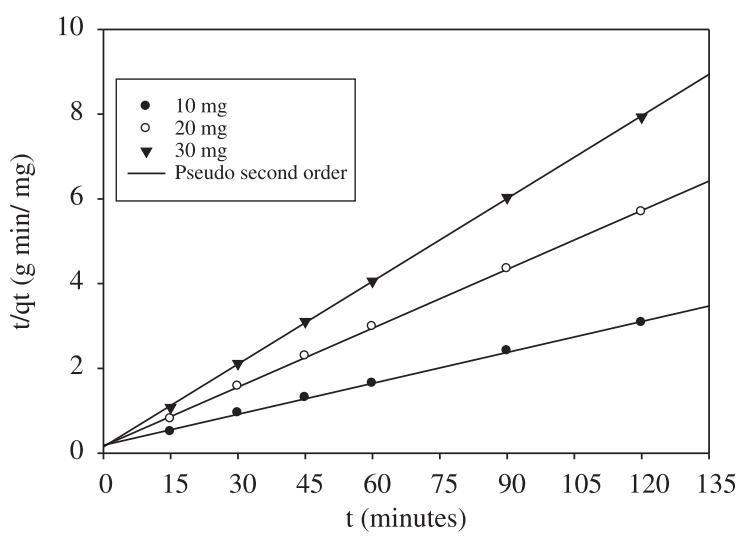

(b2)

Figure 5. a-1) The pseudo-first-order and a-2) the pseudo-second-order rate equation plots of Pt adsorbed onto the activated pistachio nut shell, and b-1) the pseudo-first-order and b-2) the pseudo-second-order rate equation plots of Pt adsorbed onto rice husk $\left(25^{\circ} \mathrm{C}, 100 \mathrm{rpm}\right.$, $\mathrm{pH}=1.5$, and $5 \mathrm{cc}$ of $100 \mathrm{ppm}$ ).

The plot of $t$ /qt versus $t$ yields a straight line that allows calculation of $\mathrm{k}_{2}$, as shown in Figure 5 The linear model exhibited a good fit for the two biosorbents.

Application of the different kinetic models revealed interesting features regarding the mechanism and the ratecontrolling step in the overall sorption process.

The kinetic parameters of both the activated pistachio nut shell and the rice husk under different conditions were calculated and are given in Table 1. To quantify the applicability of each model, the correlation coefficient $\left(\mathrm{R}^{2}\right)$ was calculated from these plots. The fits showed that the pseudo-second-order rate equation, an indication of a chemisorptions mechanism, is a better fit $\left(R^{2} \geq 0.99\right)$ than the pseudo-first-order rate equation $\left(R^{2}<<0.99\right)$ (Table 1$)$.

\subsection{Effect of temperature on platinum adsorption (\%)}

In this experimental series, the effect of temperature on platinum uptake $(\%)$ was studied in the range of $25{ }^{\circ} \mathrm{C}$ to $45^{\circ} \mathrm{C}$. Figure 6 presents the platinum uptake percentage as a function of temperature.

Figure $6 \mathrm{a}, \mathrm{b}$ show that temperature has little influence on the adsorption percentage for the activated pistachio nut shell. After 120 minutes, only an approximately $10 \%$ increment was obtained when the temperature increased from $25{ }^{\circ} \mathrm{C}$ to $45^{\circ} \mathrm{C}$. The platinum uptakes versus time curves at different temperatures are smooth and continuous, gradually leading to saturation, which indicates monolayer coverage of metal ions on the surface of the adsorbent ${ }^{24}$.

\subsection{Effect of solution $\mathrm{pH}$ on platinum adsorption} (\%)

In this experimental series, the effect of solution $\mathrm{pH}$ on platinum uptake (\%) was studied using 20 and $30 \mathrm{mg}$ sorbent dosage at room temperature for 1 hour. Figure 7 presents the platinum uptake (\%) with to the solution $\mathrm{pH}$.

As is seen in Figure 7, increasing the solution $\mathrm{pH}$ resulted in higher platinum adsorption (\%) by the rice husk. However, decreasing the solution of $\mathrm{pH}$ resulted in lower adsorption percentage by the activated pistachio nut shell. It can be concluded that platinum uptake should be carried out under acidic media ${ }^{25}$.

\subsection{Investigation of adsorption isotherms}

Adsorption isotherms of platinum ions on these sorbents were studied at three different temperatures, specifically, $25^{\circ} \mathrm{C}, 35^{\circ} \mathrm{C}$, and $45^{\circ} \mathrm{C}$, by ranging the initial concentrations of the solutions from $100 \mathrm{ppm}$ to $250 \mathrm{ppm}$ while keeping all other parameters constant. 
Table 1. Pseudo-first-order and pseudo-second-order rate equation constants for platinum adsorption on the activated pistachio nut shell and rice husk.

\begin{tabular}{|c|c|c|c|c|c|c|}
\hline \multicolumn{4}{|c|}{ Activated pistachio nut shells } & \multicolumn{3}{|c|}{ Rice husk } \\
\hline \multicolumn{7}{|c|}{ Pseudo-first-order rate equation constants (Lagergren rate constants) } \\
\hline Amount of sorbent & $\mathrm{k}_{\mathrm{ad}}\left(\min ^{-1}\right)$ & $\mathrm{q}_{\mathrm{e}}\left(\mathrm{mg} \cdot \mathrm{g}^{-1}\right)$ & $\mathrm{R}^{2}$ & $\mathrm{k}_{\mathrm{ad}}\left(\min ^{-1}\right)$ & $\mathrm{q}_{\mathrm{e}}\left(\mathrm{mg} \cdot \mathrm{g}^{-1}\right)$ & $\mathrm{R}^{2}$ \\
\hline $10 \mathrm{mg}$ & 0.0171 & 1.84 & 0.2543 & 0.0438 & 29.02 & 0.8562 \\
\hline $20 \mathrm{mg}$ & 0.0280 & 3.24 & 0.9160 & 0.0291 & 5.09 & 0.9549 \\
\hline $30 \mathrm{mg}$ & 0.0315 & 2.25 & 0.7802 & 0.0268 & 2.23 & 0.9632 \\
\hline \multicolumn{7}{|c|}{ Pseudo-second-order rate equation constants } \\
\hline Amount of sorbent & $\mathrm{k}_{2}\left(\mathrm{~g} \cdot \mathrm{min}^{-1} \cdot \mathrm{mg}^{-1}\right)$ & $\mathrm{q}_{\mathrm{e}}\left(\mathrm{mg} \cdot \mathrm{g}^{-1}\right)$ & $\mathrm{R}^{2}$ & $\mathrm{k}_{2}\left(\mathrm{~g} \cdot \mathrm{min}^{-1} \cdot \mathrm{mg}^{-1}\right)$ & $\mathrm{q}_{\mathrm{e}}\left(\mathrm{mg} \cdot \mathrm{g}^{-1}\right)$ & $\mathrm{R}^{2}$ \\
\hline $10 \mathrm{mg}$ & 0.0288 & 36.63 & 0.9993 & 0.0032 & 41.15 & 0.9986 \\
\hline $20 \mathrm{mg}$ & 0.0208 & 23.09 & 0.9998 & 0.0127 & 21.60 & 0.9995 \\
\hline $30 \mathrm{mg}$ & 0.0288 & 16.39 & 0.9997 & 0.0289 & 15.36 & 0.9999 \\
\hline
\end{tabular}

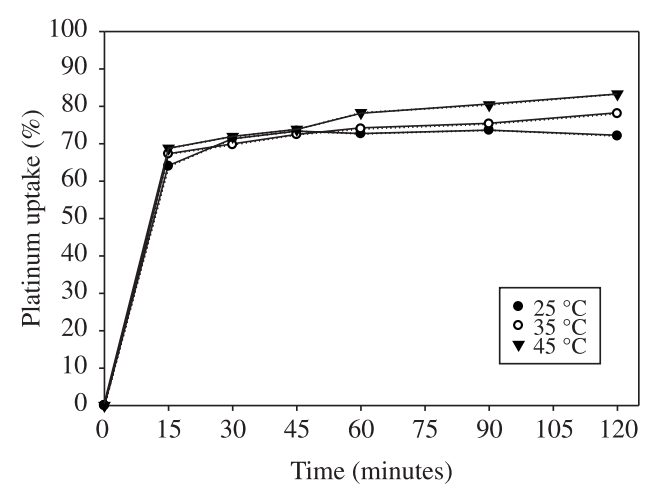

(a)

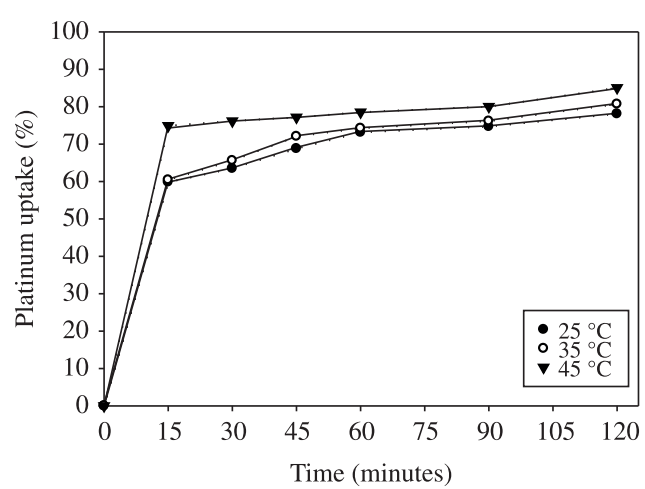

(b)

Figure 6. Platinum uptake (\%) as a function of temperature by a) the activated pistachio nut shell; b) Rice husk (10 mg, $100 \mathrm{ppm}, 100 \mathrm{rpm}$, $\mathrm{pH}=1.5$, and $5 \mathrm{cc} \mathrm{sol}$.).

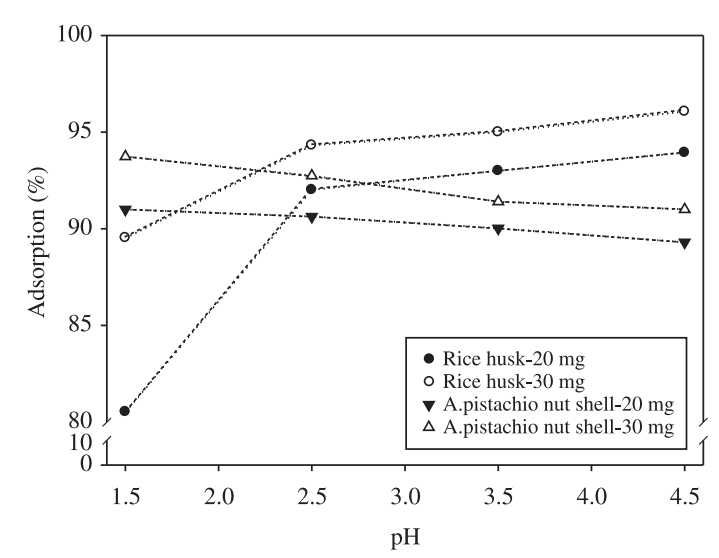

Figure 7. Platinum uptake $(\%)$ as a function of solution $\mathrm{pH}$ by the Activated pistachio nut shell and Rice husk $\left(25^{\circ} \mathrm{C}, 60\right.$ minutes, $100 \mathrm{rpm}, 5 \mathrm{cc}$ sol. of $100 \mathrm{ppm})$.

The equilibrium data obtained were analyzed with respect to the Langmuir and Freundlich isotherms.

\subsubsection{Freundlich isotherms}

The data obtained for the adsorption of platinum ions onto sorbents at an equilibrium concentration, $\mathrm{C}_{\mathrm{o}}$, ranging from 100 to $250 \mathrm{ppm}$ complied with the Freundlich equation. The following linearized form of the Freundlich equation was used ${ }^{26}$ : $\log q_{e}=\log K_{f}+1 / n \log C_{e}$

in which, $\mathrm{q}_{\mathrm{e}}$ is the amount of metal ions adsorbed at equilibrium per unit weight of sorbent $\left(\mathrm{mg} \cdot \mathrm{g}^{-1}\right), \mathrm{C}_{\mathrm{e}}$ is the equilibrium ion concentration present in the solution after adsorption, $\mathrm{K}_{\mathrm{f}}$ is the empirical Freundlich constant or the capacity factor (in mg. $\mathrm{g}^{-1}$ or mol. $\mathrm{L}^{-1}$ ), and $1 / \mathrm{n}$ is the Freundlich isotherm constant. The constants $\mathrm{K}_{\mathrm{f}}$ and $\mathrm{n}$ are empirical constants that are characteristic of the system and depend on the nature of the sorbent, the nature of the sorbate, temperature, and pressure.

The plots of $\log q_{e}$ versus $\log C_{e}$ for platinum ions adsorption onto the activated pistachio nut shells and the rice husk yield straight lines with positive slopes, given by $1 / \mathrm{n}$, and intercepts at $\log \mathrm{K}_{\mathrm{f}}$, as shown in Figure 8.

\subsubsection{Langmuir isotherms}

The following linearized form of the Langmuir equation was used to analyze the adsorption data for the adsorption of platinum on the activated pistachio nut shells and the rice husk, respectively. The Langmuir equation is provided below ${ }^{27}$ :

$C_{e} / q_{e}=1 /\left(Q_{\max } * K_{L}\right)+\left(1 / Q_{\max }\right) * C_{e}$

where $\mathrm{q}_{\mathrm{e}}$ is the amount of metal ions adsorbed at equilibrium per unit weight of sorbent $\left(\mathrm{mg}_{\mathrm{g}} \mathrm{g}^{-1}\right), \mathrm{C}_{\mathrm{e}}$ is the equilibrium concentration of the sorbate in solution following adsorption, 


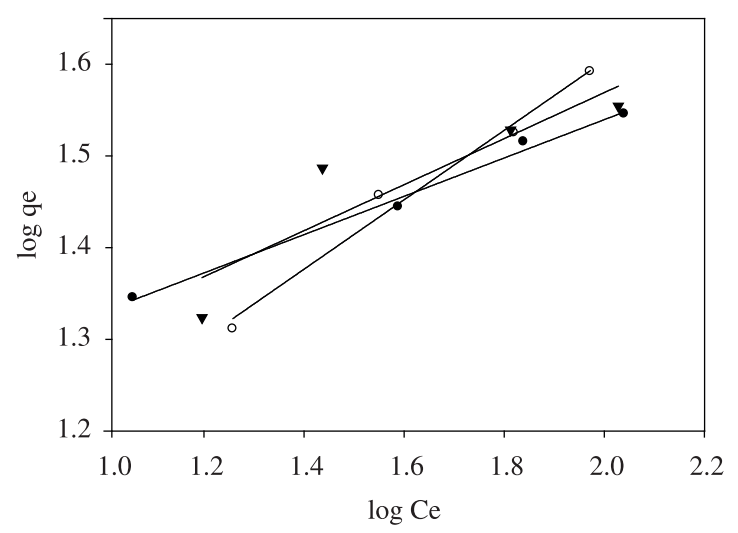

(a1)

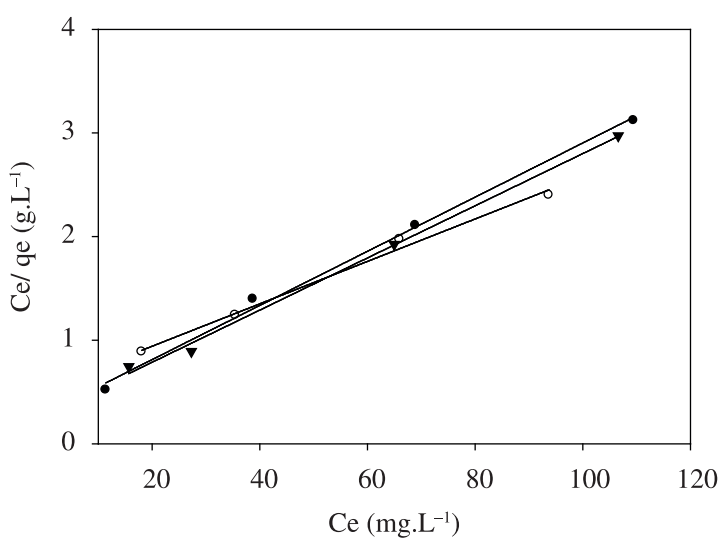

(a2)

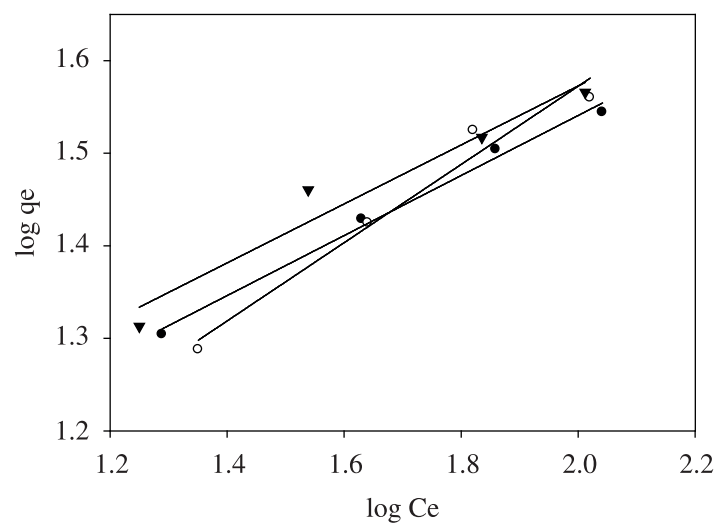

(b1)

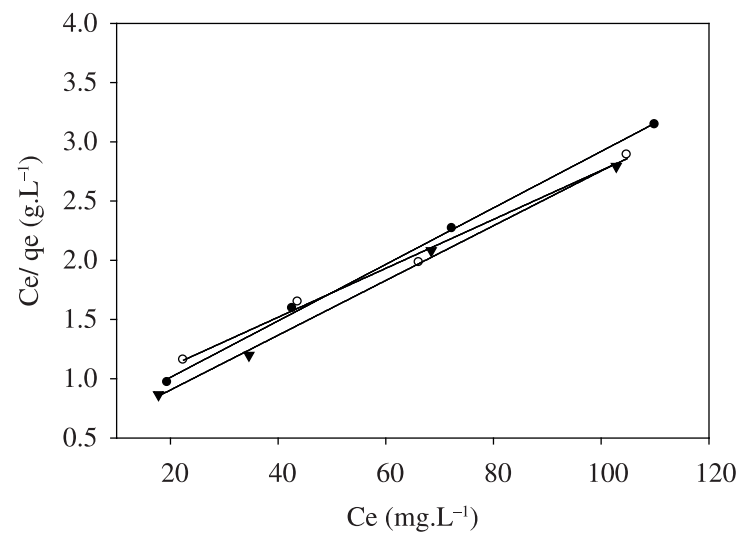

(b2)

Figure 8. a-1) The Freundlich and a-2) the Langmuir isotherm of Pt adsorbed onto the activated pistachio nut shell, and b-1) the Freundlich and b-2) the Langmuir isotherm of Pt adsorbed onto rice husk (20 mg sorbent, 60 minutes, $100 \mathrm{rpm}, \mathrm{pH}=1.5$, and $5 \mathrm{cc}$ sol. at a concentration of $100-250 \mathrm{ppm})$.

$\mathrm{Q}_{\max }$ is the maximum adsorption capacity $\left(\mathrm{mg} \cdot \mathrm{g}^{-1}\right)$ (which is generally called the monolayer capacity), and $\mathrm{K}_{\mathrm{L}}$ is the Langmuir equilibrium constant $\left(\mathrm{L}_{\mathrm{mg}} \mathrm{mg}^{-1}\right)$. Figure 8 shows the Langmuir adsorption isotherm plot of $\mathrm{C}_{e} / \mathrm{q}_{\mathrm{e}}$ versus $\mathrm{C}_{\mathrm{e}}$.

The adsorption isotherms of both activated pistachio nut shell and rice husk under different conditions were calculated and given in Table 2 . The values of each model and the correlation coefficient, $\mathrm{R}^{2}$, were calculated from these plots. The linearity of these plots indicates the applicability of the two models. The correlation coefficients, $R^{2}$, showed that the Langmuir isotherm $\left(R^{2} \geq 0.99\right)$ fits better than the Freundlich isotherm $\left(R^{2}<0.99\right)$. This result indicates that the adsorption process of platinum ion onto the surfaces of rice husk and activated pistachio nut shell is a monolayer adsorption process.

The comparison of the adsorption capacity of the activated pistachio nut shell and rice husk with some previously used adsorbent is provided in Table 3 . The results show that the activated pistachio nut shell and rice husk are very effective for the removal of platinum ions from aqueous solutions, and the maximum monolayer adsorption capacities, $\mathrm{Q}_{\max }$, of platinum uptake obtained by the activated pistachio nut shell and rice husk were comparable with the data presented by scientific literature ${ }^{11,20,32,33}$. The adsorption capacities of activated pistachio nut shell and rice husk were much higher than that of commercial adsorbents such as activated carbon but similar adsorption capacities to other adsorbents was obtained as shown in Table 3. According to the results obtained, activated pistachio nut shell and rice husk could be employed as low-cost adsorbents and could be considered as an alternative to commercial sorbents for the adsorption of platinum from industrial effluents.

\subsection{Investigation of adsorption thermodynamics}

The temperature range chosen in this study was $298 \mathrm{~K}$ to $318 \mathrm{~K}$. The uptake percentage increases with increasing temperature. Thermodynamic parameters for this uptake process, such as enthalpy change $\left(\Delta \mathrm{H}^{\circ}\right)$, entropy change $\left(\Delta \mathrm{S}^{\circ}\right)$, and the free energy of specific adsorption $\left(\Delta \mathrm{G}^{\circ}\right)$, was calculated using the following equations ${ }^{24,28,29}$ :

$\mathrm{K}_{c}=\mathrm{C}_{A C} / \mathrm{C}_{e}$

where $\mathrm{K}_{\mathrm{c}}$ is the equilibrium constant, $\mathrm{C}_{\mathrm{AC}}$ and $\mathrm{C}_{\mathrm{e}}$ are the equilibrium concentrations (in $\mathrm{mg} . \mathrm{L}^{-1}$ ) of the platinum ion adsorbed and left in the solution, respectively. $\Delta \mathrm{G}^{\circ}$ was calculated using the following relationship:

$\Delta \mathrm{G}=\Delta \mathrm{G}^{\circ}+\mathrm{RT} \ln \mathrm{K}_{c}$ 
Table 2. Freundlich and Langmuir constants for the adsorption of platinum at various temperatures.

\begin{tabular}{|c|c|c|c|c|c|c|}
\hline \multicolumn{4}{|c|}{ Activated pistachio nut shells } & \multicolumn{3}{|c|}{ Rice husk } \\
\hline \multicolumn{7}{|c|}{ Freundlich isotherm constants } \\
\hline Temp. & $\mathrm{K}_{\mathrm{f}}\left(\mathrm{mg} \cdot \mathrm{g}^{-1}\right)^{*}\left(\mathrm{~L} \cdot \mathrm{mg}^{-1}\right)^{1 / n}$ & $\mathrm{n}$ & $\mathrm{R}^{2}$ & $\mathrm{~K}_{\mathrm{f}}\left(\mathrm{mg} \cdot \mathrm{g}^{-1}\right) *\left(\mathrm{~L} \cdot \mathrm{mg}^{-1}\right)^{1 / \mathrm{n}}$ & $\mathrm{n}$ & $\mathrm{R}^{2}$ \\
\hline $25^{\circ} \mathrm{C}$ & 13.23 & 4.78 & 0.9820 & 7.80 & 3.08 & 0.9916 \\
\hline $35^{\circ} \mathrm{C}$ & 11.67 & 3.98 & 0.8170 & 8.62 & 3.14 & 0.9700 \\
\hline $45^{\circ} \mathrm{C}$ & 7.02 & 2.64 & 0.9817 & 5.33 & 2.37 & 0.9519 \\
\hline \multicolumn{7}{|c|}{ Langmuir isotherm constants } \\
\hline Temp. & $\mathrm{K}_{\mathrm{L}}\left(\mathrm{L} \cdot \mathrm{mg}^{-1}\right)$ & $\mathrm{Q}_{\max }\left(\mathrm{mg} \cdot \mathrm{g}^{-1}\right)$ & $\mathrm{R}^{2}$ & $\mathrm{~K}_{\mathrm{L}}\left(\mathrm{L} \cdot \mathrm{mg}^{-1}\right)$ & $\mathrm{Q}_{\max }\left(\mathrm{mg} \cdot \mathrm{g}^{-1}\right)$ & $\mathrm{R}^{2}$ \\
\hline $25^{\circ} \mathrm{C}$ & 0.09 & 38.31 & 0.9959 & 0.04 & 42.02 & 0.9989 \\
\hline $35^{\circ} \mathrm{C}$ & 0.09 & 39.68 & 0.9923 & 0.05 & 43.29 & 0.9938 \\
\hline $45^{\circ} \mathrm{C}$ & 0.07 & 49.31 & 0.9966 & 0.03 & 48.54 & 0.9974 \\
\hline
\end{tabular}

Table 3. Maximum adsorption capacities for the adsorption of platinum ions, onto various adsorbents reported in the literature.

\begin{tabular}{lccc}
\hline \multicolumn{1}{c}{ Adsorbents } & $\mathbf{Q}_{\text {max }}\left(\mathbf{m g . g}^{-1}\right)$ & pH & Reference \\
\hline Lewatit MP 600 WS & 40.43 & - & 11 \\
PA lignin & 42.93 & - & 32 \\
$\mathrm{Fe}_{3} \mathrm{O}_{\mathbf{4}}$ nanoparticles & 13.27 & - & 33 \\
Activated Carbon & 2.7 & 3.5 & 20 \\
Activated Pistachio nut shell & 38.31 & 1.5 & This study \\
Rice Husk & 42.02 & 1.5 & This study \\
\hline
\end{tabular}

At equilibrium, $\Delta \mathrm{G}=0$, thus

$\Delta \mathrm{G}^{\circ}=-\mathrm{RT} \ln \mathrm{K}_{c}$

where $\mathrm{T}$ is absolute temperature in Kelvin, and $\mathrm{R}$ is the gas constant.

$\Delta \mathrm{H}^{\circ}$ was calculated from the following equations:

$\Delta \mathrm{G}^{\circ}=\Delta \mathrm{H}^{\circ}-\mathrm{T} \Delta \mathrm{S}^{\circ}$

$\ln \mathrm{K}_{c}=\Delta \mathrm{S}^{\circ} / \mathrm{R}-\Delta \mathrm{H}^{\circ} / \mathrm{RT}$

The enthalpy change $\left(\Delta \mathrm{H}^{\circ}\right)$, and the entropy change $\left(\Delta \mathrm{S}^{\circ}\right)$ were calculated from the slope and from the intercept in linear plots of $\ln \mathrm{K}_{\mathrm{c}}$ versus $1000 / \mathrm{T}$, as shown in Figure 9.

The free energy of adsorption $\left(\Delta \mathrm{G}^{\circ}\right)$ was calculated using the following equation:

$\Delta \mathrm{G}^{\circ}=-\mathrm{RT} \ln \mathrm{K}_{c}$

The values of the thermodynamic parameters, $\Delta \mathrm{H}^{\circ}, \Delta \mathrm{S}^{\circ}$, and $\Delta \mathrm{G}^{\circ}$ for the platinum uptake onto the activated pistachio nut shells and rice husk were calculated using equations 9-13 and are given in Table 4.

As shown in Figure 6, an increase in the value of the uptake percentage with increasing temperature indicates the endothermic character of platinum uptake onto the sorbents. The value of $\Delta \mathrm{H}^{\circ}{ }_{298 \mathrm{~K}}$ for the platinum uptake onto the activated pistachio nut shells and rice husk are calculated

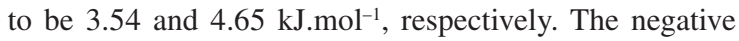
values of the free energy of specific adsorption $\left(\Delta \mathrm{G}^{\circ}\right)$ for the adsorption of platinum onto the sorbents, as shown in Table 4 , indicate that the process is spontaneous ${ }^{24}$. The value of $\Delta \mathrm{G}^{\circ}$ becomes more negative as the temperature increases, indicating an increasing driving force toward equilibrium, thereby resulting in a greater adsorption percentage at higher

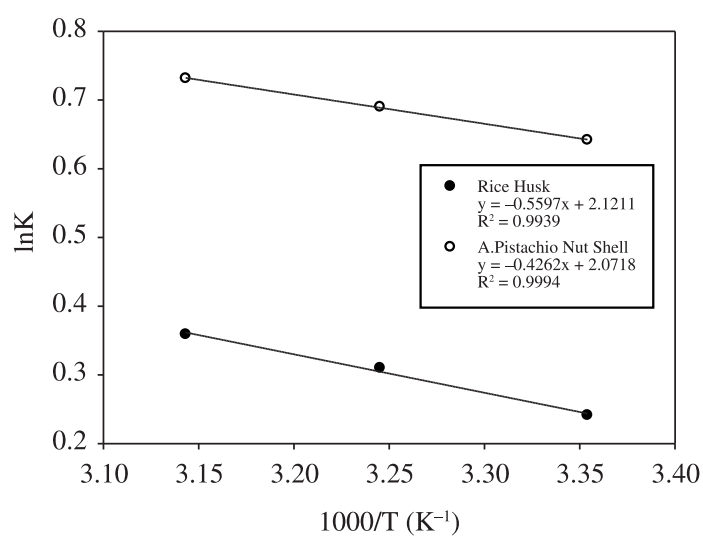

Figure 9. $\ln \mathrm{K}_{\mathrm{c}}$ versus $1000 / \mathrm{T}$ for platinum on rice husk and activated pistachio nut shells (30 mg sorbent, 60 minutes, $100 \mathrm{rpm}, \mathrm{pH}=1.5$, $\mathrm{C}_{\mathrm{o}}=200 \mathrm{ppm}$, and $5 \mathrm{cc} \mathrm{sol}$.)

temperatures. The increase in the adsorption capacity of platinum onto the sorbents at higher temperature may be attributed to an enlargement of the pore size or to increased activation of the adsorbent surface. The greater extent of platinum adsorption at higher temperatures becomes apparent in an increase in the monolayer capacity. The process can only occur spontaneously if the entropy of the system increases and the value of $\mathrm{T} \cdot \Delta \mathrm{S}^{\circ}$ becomes greater than the value of $\Delta \mathrm{H}^{\circ}$, yielding a negative value for the free energy of specific adsorption, $\Delta \mathrm{G}^{\circ}$. The adsorption of platinum onto the sorbents is accompanied by an increase in the entropy of the overall system. The positive value of $\Delta \mathrm{S}^{\circ}$ indicates an increase in the randomness at the solid/ solution interface during the adsorption of the metal ion onto the activated pistachio nut shells and rice husk. The results are in good agreement with those of other base metal ions adsorbed onto rice husk ${ }^{30}$ and activated pistachio nut shells ${ }^{31}$.

\subsection{Characterization of sorbents}

Figure 10a-d display SEM images of the adsorbed platinum ions before and after activated pistachio nut shell and rice husk, respectively.

Figure 10a shows that the pistachio nut shell activated carbon had a porous structure, an observation supported by the BET surface area $\left(141.18 \mathrm{~m}^{2} \cdot \mathrm{g}^{-1}\right)$ of this activated pistachio nut shell. As can be seen in Figure 10b, most of the adsorbed platinum ions were located inside the pores. 
Table 4. Thermodynamic constants for the adsorption of platinum at various temperatures.

\begin{tabular}{|c|c|c|c|c|c|c|}
\hline \multicolumn{4}{|c|}{ Activated pistachio nut shells } & \multicolumn{3}{|c|}{ Rice husk } \\
\hline \multicolumn{7}{|c|}{ Thermodynamic constants } \\
\hline $\begin{array}{l}\text { Temp. } \\
\text { (K) }\end{array}$ & $\begin{array}{c}\Delta \mathrm{G}^{\circ} \\
\left(\mathrm{kJ} \cdot \mathrm{mol}^{-1}\right)\end{array}$ & $\begin{array}{c}\Delta \mathrm{H}^{\circ}{ }_{298 \mathrm{~K}} \\
\left(\mathrm{~kJ} \cdot \mathrm{mol}^{-1}\right)\end{array}$ & $\begin{array}{c}\Delta \mathrm{S}^{\circ}{ }_{298 \mathrm{~K}} \\
\left(\mathrm{~J} . \mathrm{mol}^{-1} \cdot \mathrm{K}^{-1}\right)\end{array}$ & $\begin{array}{c}\Delta \mathrm{G}^{\circ} \\
\left(\mathrm{kJ} \cdot \mathrm{mol}^{-1}\right)\end{array}$ & $\begin{array}{c}\Delta \mathrm{H}^{\circ}{ }_{298 \mathrm{~K}} \\
\left(\mathrm{~kJ} \cdot \mathrm{mol}^{-1}\right)\end{array}$ & $\begin{array}{c}\Delta \mathrm{S}^{\circ}{ }_{298 \mathrm{~K}} \\
(\mathrm{~J} / \mathrm{mol} \mathrm{K})\end{array}$ \\
\hline 298 & -1.59 & 3.54 & 17.2 & -0.60 & 4.65 & 17.6 \\
\hline 308 & -1.77 & & & -0.79 & & \\
\hline 318 & -1.94 & & & -0.95 & & \\
\hline
\end{tabular}

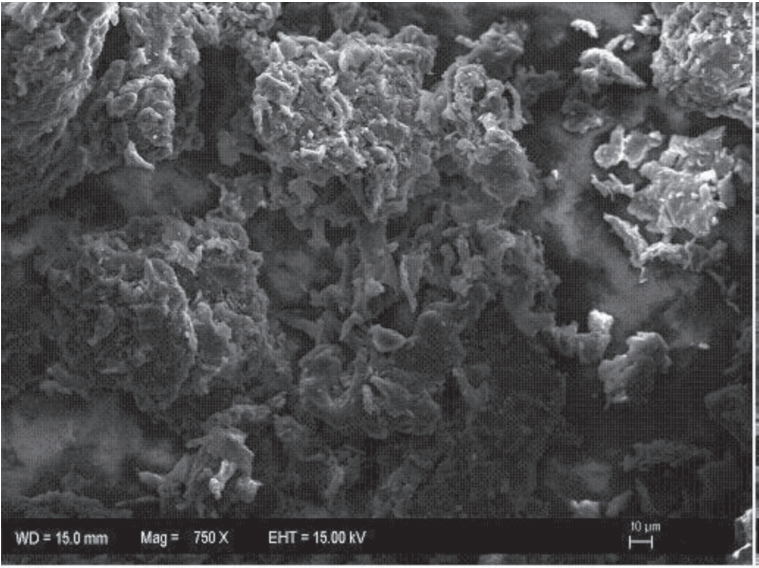

(a)

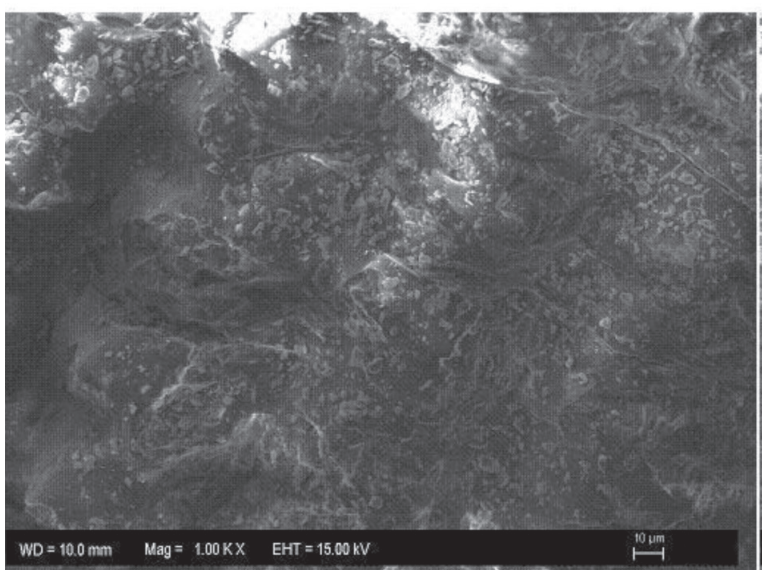

(c)

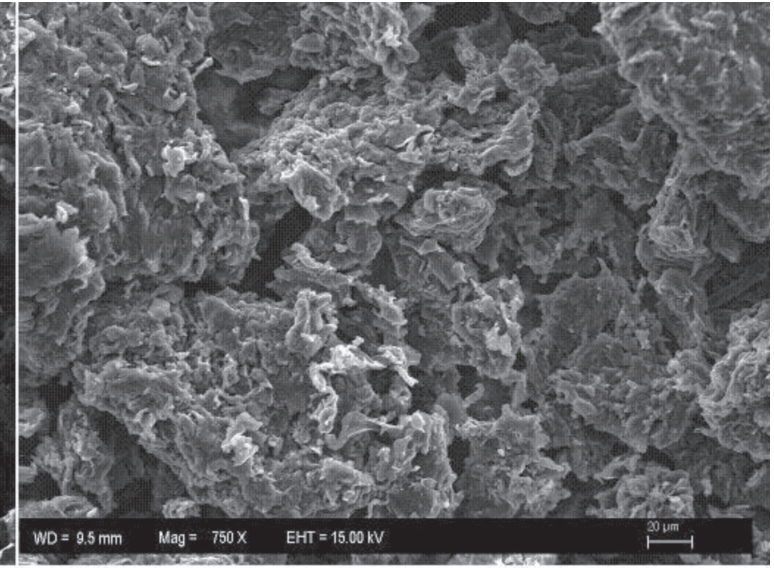

(b)

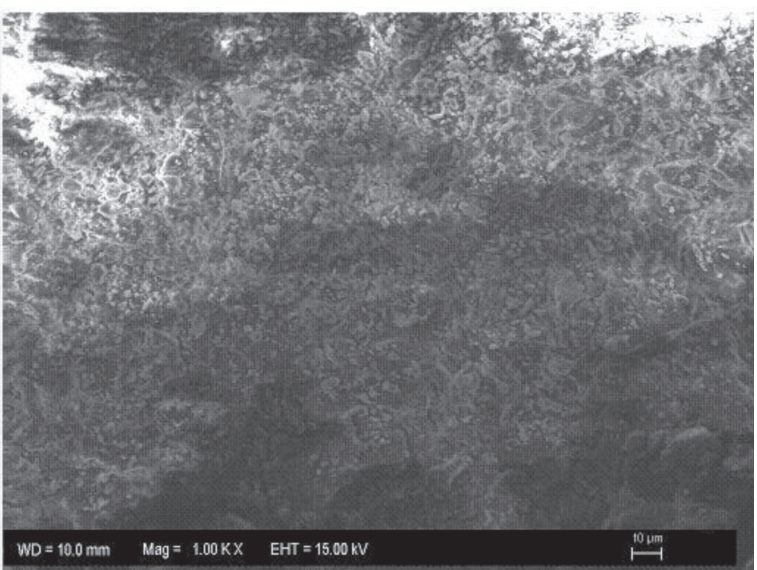

(d)

Figure 10. SEM images of a) Original Pistachio nut shell; b) after adsorbed platinum on Activated pistachio nut shell; c) Original Rice husk; d) after treatment Rice husk.

As can be seen in Figure 10c; rice husk also had a porous structure. However, the platinum ion adsorption capacity of this material was different from that of activated pistachio nut shell. Indeed, Figure 10d indicates that most of the platinum ions adsorbed onto these biosorbents were located on the surface rather than inside the pores.

As mentioned above, the surface morphology and other properties of biosorbents influence their adsorption capacities. Rice husk had a more porous structure and a higher surface area than activated pistachio nut shell; hence, it would be expected to have a greater adsorption capacity relative to rice husk.

\section{Conclusion}

This study explored the possibility of platinum adsorption from dilute platinum chloride solutions using biosorbents (activated pistachio nut shell and rice husk). Platinum uptake (\%) of $\geq 95 \%$ was easily attainable using excessive amounts of activated pistachio nut shell ( $\geq 40 \mathrm{mg})$ and rice husk ( $\geq 40 \mathrm{mg}$ ) at $100 \mathrm{rpm}$ with 60 minutes. of contact time, even at room temperature. Additionally, increasing the temperature from $25{ }^{\circ} \mathrm{C}$ to $45{ }^{\circ} \mathrm{C}$ enabled the platinum uptake (\%) of $\geq 90 \%$ using smaller amount of activated pistachio nut shell $(20 \mathrm{mg})$ and rice husk 
(30 mg) under the same conditions. Thus, temperature was demonstrated to be effective in platinum uptake $(\%)$, which is in accordance with the scientific literature.

Equilibrium adsorption data were well fit the Langmuir model $\left(\mathrm{R}^{2} \geq 0.99\right)$. The adsorption maximum capacities, $\mathrm{Q}_{\max }$, at $25^{\circ} \mathrm{C}$ of platinum ions onto activated pistachio nut shell and rice husk were found to be 38.31 and $42.02 \mathrm{mg} . \mathrm{g}^{-1}$, respectively. Adsorption of platinum ions followed the pseudo-second-order rate equation, with a correlation coefficient of 0.99 , rather than the pseudo-first-order rate equation. The enthalpy change $\left(\Delta \mathrm{H}^{\circ}{ }_{298 \mathrm{~K}}\right)$ and the entropy change $\left(\Delta \mathrm{S}^{\circ}{ }_{298 \mathrm{~K}}\right)$ for this adsorption process for the activated

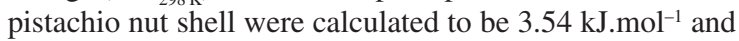
$17.2 \mathrm{~J} . \mathrm{mol}^{-1} \cdot \mathrm{K}^{-1}$, respectively, and the same quantities

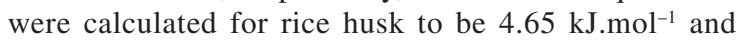
$17.6 \mathrm{~J} . \mathrm{mol}^{-1} \cdot \mathrm{K}^{-1}$, respectively. Thus, the adsorption process was found to be spontaneous and endothermic.

This study demonstrates that platinum recovery can successfully be achieved using biosorbents, which are

\section{References}

1. Aktas $\mathrm{S}$ and Morcali H. Platinum recovery from dilute platinum solutions using activated carbon. Transactions of Nonferrous Metals Society of China. 2011;21(11):2554-2558. http://dx.doi. org/10.1016/S1003-6326(11)61091-1

2. Netzer A and Hughes DE. Adsorption of copper, lead and cobalt by activated carbon. Water Research. 1984; 18(8):927-933. http://dx.doi.org/10.1016/0043-1354(84)90241-0

3. Ngah WSW, Endud CS and Mayanar R. Removal of copper(II) ions from aqueous solution onto chitosan and cross-linked chitosan beads. Reactive and Functional Polymers. 2002; 50(2):181-190. http://dx.doi.org/10.1016/ S1381-5148(01)00113-4

4. Wang K and Xing B. Adsorption and desorption of cadmium by goethite pre-treated with phosphate. Chemosphere. 2002; 48(7):665-670. http://dx.doi.org/10.1016/S00456535(02)00167-4

5. Keith KHC and Gordon M. Sorption of cadmium, copper, and zinc ions onto bone char using Crank diffusion model. Chemosphere. 2005; 60:1141-1150.

6. Cheung $\mathrm{KC}$ and Venkitachalam TH. Improving phosphate removal of sand infiltration system using alkaline fly ash. Chemosphere. 2000; 41(1-2):243-249. http://dx.doi. org/10.1016/S0045-6535(99)00417-8

7. Rao M, Parwate AV and Bhole AG. Removal of $\mathrm{Cr}^{6+}$ and $\mathrm{Ni}^{2+}$ from aqueous solution using bagasse and fly ash. Waste Management. 2002; 22:821-830.

8. Yildiz E. Phosphate removal from water by fly ash using cross flow micro-filtration. Separation and Purification Technology. 2004; 35(3):241-252. http://dx.doi.org/10.1016/ S1383-5866(03)00145-X

9. Gray CA and Schwab AP. Phosphorus-fixing ability of high $\mathrm{pH}$, high calcium coal-combustion waste materials. Water, Air, Soil Pollution. 1993; 69(3-4):309-320. http://dx.doi.org/10.1007/ BF00478167

10. Guibal E, Vincent T, Larkin A and Tobin JM. Chitosan sorbents for platinum recovery from dilute solutions. Industrial \& Engineering Chemistry Research. 1999; 38(10):4011-4022. http://dx.doi.org/10.1021/ie990165k abundant and readily available in Turkey, as an alternative to more costly materials for the treatment of waste solutions containing heavy metal ions. These promising results suggest that platinum containing waste solutions such as catalytic converter leach solutions, anode slime solutions etc. can be successfully treated. Best of all, this method does not involve using any chemicals, so it does not generate any hazardous byproducts. For the future studies, activated pistachio nut shell and rice husk should be tested for adsorption of other precious metals such as rhodium and palladium, and compared with commercial products such as activated carbon, which has been frequently employed in industry.

\section{Acknowledgements}

The authors thank Tubitak and Istanbul Technical University for their financial support. We particularly thank Gazi Fistikcilik for providing the pistachio nut shells.

11. Kononova ON, Leyman TA, Melnikov AM, Kashirin DM and Tselukovskaya MM. Ion exchange recovery of platinum from chloride solutions. Hydrometallurgy. 2010; 100(3-4):161-167. http://dx.doi.org/10.1016/j.hydromet.2009.11.011

12. Romero LC, Bonomo A and Gonzo EE. Acid-activated carbons from peanut shells: synthesis, characterization and uptake of organic compounds from aqueous solutions. Adsorption Science and Technology. 2001; 21:617-626.

13. Ozer A and Dursun G. Removal of methylene blue from aqueous solution by dehydrated wheat bran carbon. Journal of Hazardous Materials. 2007; 146(1-2):262-269. http://dx.doi. org/10.1016/j.jhazmat.2006.12.016

14. Hashem A, Aly AA, Aly AS and Hebeish A. Quaternization of cotton stalks and Palm tree particles for removal of acid dye from aqueous solutions. Polymer-Plastics Technology and Engineering. 2006; 45(3):389. http://dx.doi. org/10.1080/03602550600553689

15. Robinson T, Chandran B and Nigam P. Removal of dyes from an artificial textile dye effluent by two agricultural waste residues, corncob and barley husk. Environment International. 2002; 28(1-2):29-33. http://dx.doi.org/10.1016/S01604120(01)00131-3

16. Mohamed MM. Acid dye removal: comparison of surfactant modified mesoporous FSM with activated carbon derived from rice husk. Journal of Colloid and Interface Science. 2004; 272(2):28-34. http://dx.doi.org/10.1016/j.jcis.2003.08.071

17. Tseng RL, Wu FC and Juang RS. Liquid-phase adsorption of dyes and phenols using pinewood-based activated carbons. Carbon. 2003; 41(3):487-495. http://dx.doi.org/10.1016/ S0008-6223(02)00367-6

18. Mokhtar A, Nargess YL, Niyaz MM and Nooshin ST. Equilibrium and Kinetics studies for the adsorption of direct and acid dyes from aqueous solution by soy meal hull. Journal of Hazardous Materials. 2006; 135(1-3):171-179.

19. Tóth J. Adsorption: Theory, Modeling and Analysis, Marcel Dekker Inc.: New York; 2001.

20. Aktas S and Morcali MH. Gold uptake from dilute chloride solutions by a Lewatit TP 214 and activated rice husk. International Journal of Mineral Processing. 2011; 101(1-4):63-70. http:// dx.doi.org/10.1016/j.minpro.2011.07.007 
21. Yang $\mathrm{T}$ and Lua AC, Characteristics of activated carbons prepared from pistachio-nut shells by physical activation. Journal of Colloid and Interface Science. 2003; 267(2):408417. http://dx.doi.org/10.1016/S0021-9797(03)00689-1

22. Ozcimen D and Ersoy-Meriçboyu A. Adsorption of Copper(II) Ions onto Hazelnut Shell and Apricot Stone Activated Carbons. Adsorption Science and Technology. 2010; (28):327-340. http:// dx.doi.org/10.1260/0263-6174.28.4.327

23. Pearson RG. Chemical Hardness. Weinheim: WileyVCH; 1997. http://dx.doi.org/10.1002/3527606173

24. Hussain G and Khan MA. Adsorption of Gold (III) from Aqueous Solutions on Bagasse Ash. Journal of the Chemical Society of Pakistan. 2011; 33:317-323.

25. Zhou L, Xua J, Lianga X and Liub Z. Adsorption of platinum(IV) and palladium(II) from aqueous solution bymagnetic crosslinking chitosan nanoparticles modified with ethylenediamine. Journal of Hazardous Materials. 2010; 182(1-3):518-524. http://dx.doi.org/10.1016/j.jhazmat.2010.06.062

26. Freundlich HMF. Over the adsorption in solution. Journal of Physical Chemistry. 1906; 57:385-407.

27. Langmuir I. The adsorption of gases on plane surfaces of glass, mica and platinum. Journal of the American Chemical Society. 1918; 40(9):1361-1403. http://dx.doi.org/10.1021/ ja02242a004

28. Jaman H, Chakraborty D, Saha P. A Study of the thermodynamics and kinetics of Copper adsorption using chemically modified rice husk. Clean: Soil, Air, Water. 2009; 37:704-711. http:// dx.doi.org/10.1002/clen.200900138

29. Kula I, Ugurlu M, Kaleaoglu H and Celik A. Adsorption of $\mathrm{Cd}$ (II) ions from aqueous solutions using activated carbon prepared from olive stone by $\mathrm{ZnCl}_{2}$ activation. Bioresource Technology. 2008; 99(3):492-501. http://dx.doi.org/10.1016/j. biortech.2007.01.015

30. Won SW, Park J, Mao J and Yun YS. Utilization of PEImodified Corynebacterium glutamicum biomass for the recovery of Pd (II) in hydrochloric solution. Bioresource Technology. 2011; 102(4):3888-3893. http://dx.doi. org/10.1016/j.biortech.2010.11.106

31. Naeem S, Zafar U, Altaf A and Inayat A. Adsorption studies of Cr (IV) on Rice Husk Ash (Rha). Journal of the Chemical Society of Pakistan. 2009; 31:379-382.

32. Parajuli D, Kawakita H, Inoue K and Funaoka M. Recovery of gold(III), palladium(II), and platinum(IV) by aminated lignin derivatives. Industrial \& Engineering Chemistry Research. 2006; 45(19):6405-6412. http://dx.doi.org/10.1021/ ie 0603518

33. Uheida A, Iglesias M, Fontas C, Hidalgo M, Salvado V, Zhang $\mathrm{Y}$ and Muhammed M. Sorption of palladium(II), rhodium(III), and platinum(IV) on $\mathrm{Fe}_{3} \mathrm{O}_{4}$ nanoparticles. Journal of Colloid and Interface Science. 2006; 301(2):402-408. http://dx.doi. org/10.1016/j.jcis.2006.05.015 